\title{
PSYCHOSOCIAL ASPECT IN THE ACCEPTANCE OF COVID-19 VACCINES (SYSTEMATIC REVIEW)
}

\author{
Sutrani Rachmawati, Dadan Erwandi ${ }^{*}$ \\ Department of Occupational Health and Safety, Faculty of Public Health Universitas Indonesia, C Building $1^{\text {st }}$ \\ Floor Kampus Baru UI Depok 16424, Indonesia
}

\begin{abstract}
COVID-19 vaccine can protect the public and suppress COVID-19 cases. But there are still many people who refuse to be vaccinated. The study aims to analyze the psychosocial aspects in the Acceptance of COVID-19 Vaccines. This study is a systematic review with PRISMA (Preferred Reporting Items for Systematic Reviews \& Meta-Analyses). The database used to search data and information is PubMed. The keywords used during the search process are "Determinants" OR "Accepting" AND "Acceptance of COVID-19 Vaccination". The most psychosocial aspects related to COVID-19 vaccine acceptance include education level, income level, race, type of work, trust in the existence of COVID-19, trust in COVID-19 information resources, trust in medical and health workers, and having family members or friends who are infected with COVID-19. Education level, income level, and race influence the most in accepting the COVID-19 vaccine. The COVID-19 vaccine program should consider and overcome the challenges of receiving and rejecting vaccines from the public by looking at these aspects.
\end{abstract}

Keywords: COVID-19, psychosocial aspects, vaccine acceptance

\begin{abstract}
ABSTRAK
Pemberian vaksin COVID-19 dapat melindungi masyarakat dan menekan kasus COVID-19. Namun masih banyak masyarakat yang enggan untuk menerima vaksin. Tujuan studi ini untuk menganalisis aspek psikososial dalam penerimaan vaksin COVID-19. Studi ini merupakan tinjaua sistematis dengan metode PRISMA (Preferred Reporting Items for Systematic Reviews \& Meta Analyses). Database yang digunakan untuk pencarian data dan informasi adalah PubMed. Kata kunci yang digunakan saat proses pencarian adalah "Determinants" OR "Accepting" AND "Acceptance of COVID-19 Vaccination". Variabel aspek prikososial yang paling banyak berhubungan dengan peneriman vaksin COVID-19 meliputi tingkat pendidikan, tingkat pendapatan, ras, jenis pekerjaan, kepercayaan terhadap keberadaan COVID-19, kepercayaan terhadap sumber informasi COVID-19, kepercayaan terhadap medis dan tenaga kesehatan, serta memiliki anggota keluarga atau teman yang terinveksi COVID-19. Tingkat pendidikan, tingkat pendapatan, dan ras paling banyak mempengaruhi dalam penerimaan vaksin COVID-19. Program pemberian vaksin COVID-19 sebaiknya mempertimbangkan dan mengatasi tantangan penerimaan dan penolakan vaksin dari masyarakat dengan melihat aspek-aspek tersebut.
\end{abstract}

Kata kunci: COVID-19, aspek psikososial,penerimaan vaksin

Correspondence Address: Dadan Erwandi, Department of Occupational Health and Safety, Faculty of Public Health Universitas Indonesia, C Building $1^{\text {st }}$ Floor Kampus Baru UI Depok 16424, Indonesia,E-mail: dadan@ui.ac.id 


\section{Introduction}

In late December 2019, an infectious disease caused by the SARS-CoV-2 virus known as Coronavirus disease (COVID-19) first appeared in Wuhan, China. The virus spread rapidly to other countries, so that, finally on January 30, 2020, the World Health Organization (WHO) declared that the case of COVID-19 was an international public health emergency. ${ }^{1}$ Currently, the number of confirmed cases in the world reaches 180,817,269 cases (as of June 28, 2021), and in Indonesia has reached 2,135,998 confirmed cases (as of June 28, 2021). ${ }^{2,3}$

Many efforts have been made by the government or the world community related to the prevention and handling of COVID-19. One of the prevention efforts that is currently being developed and implemented is the COVID-19 vaccination program. The program started in early December 2020 by distributing 13 different types of vaccines. ${ }^{4}$ Through the vaccination, the immune system is trained to recognize targeted viruses and create antibodies to fight the disease without being exposed to the disease itself. ${ }^{5}$ After getting the vaccine, the body is ready to fight the virus if exposed to the virus to prevent the disease. The provision of The COVID-19 vaccine can protect the public and suppress the covid-19 cases currently high in various countries. According to the World Health Organization (WHO), in addition to reducing fatalities and helping to control pandemics, the provision of the Covid-19 vaccine will prevent global economic losses of US\$ 375 billion every month. ${ }^{6}$

WHO with the support of several studies has shown that the COVID-19 vaccine that has been clinically tested has proven to be safe and very effective in preventing COVID-19.5 Although has clinical trials proving that the Covid-19 vaccine is safe and effective, there are still people who are refuse to be vaccinated..$^{7-9}$ If there is still a lot of rejection of vaccines in the community, then this will complicate efforts to prevent COVID-19 so that the problem of this pandemic will be more challenging to end. Various factors affect people's willingness to receive the COVID-19 vaccination, including the safety and effectiveness of the vaccine itself, knowledge and trust in COVID-19 and vaccines, social demographics such as age, gender, educational employment status, race, and others. ${ }^{10-}$

${ }^{19}$ Based on this explanation, the researchers wanted to analyze the psychosocial aspects that affect people in the Acceptance of COVID-19 Vaccines by conducting a systematic review of literature from previous studies. The psychosocial aspects are essential to be studied further and thoroughly in the acceptance of the COVID-19 vaccine. This can be useful and become a reference for those who have a role in the COVID-19 vaccination program in approaching the community to be vaccinated. 


\section{Method}

This study used PRISMA (Preferred Reporting Items for Systematic Reviews \& Meta Analyses) by WHO as a search strategy to identify relevant studies. Through the PRISMA method, data search uses a flowchart based on a checklist consisting of identifying articles through a database, screening articles by title and abstract, assessing full text for eligibility, and analyzing articles that have qualified inclusion criteria. The database used to search for data and information in this systematic review is PubMed (https://pubmed.ncbi.nlm.nih.gov/). During the document search process, the keywords "Determinants" OR "Accepting" AND "Acceptance of COVID-19 Vaccination" are used. The inclusion criteria of documents that are considered appropriate to conduct this systematic review are articles from original research (not systematic review), the quantitative studies with various study designs, presented in english, published in the period 2020 - 2021, and open access full text. The variables included in this systematic review are only variables related to psychosocial aspects, namely relating to the interrelation of social factors, individual thought, and behavior. The exclusion criteria are studies that do not address psychosocial factors and their relationship to the acceptance of the COVID-19 vaccine is not included in the analysis. This study has been approved by the Ethical Committee of Research and Community Development, Faculty of Public Health, Universitas Indonesia, No. Ket-: 377/UN2.F10.D11/PPM.00.02/2021.

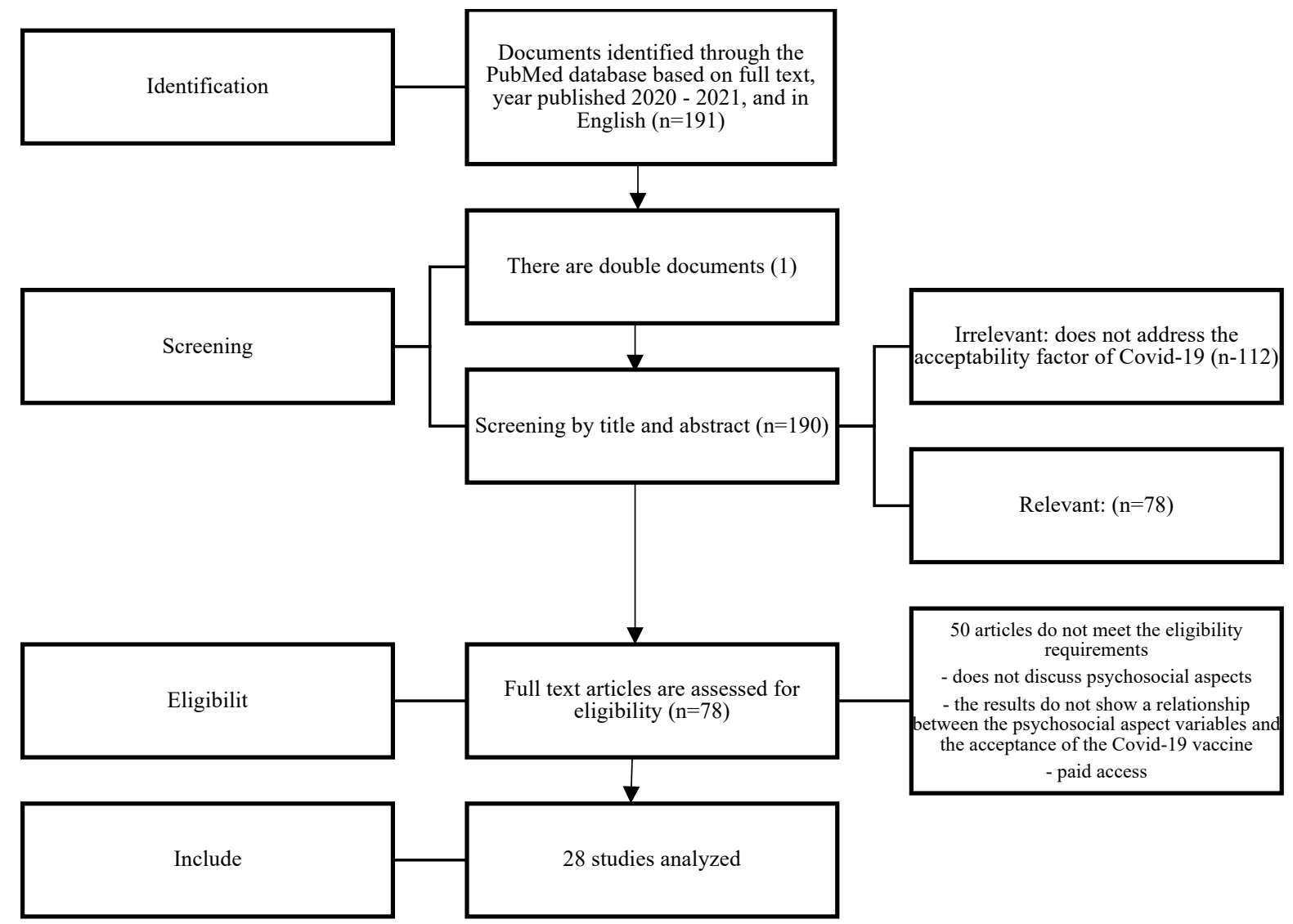

Figure 1. The literature search process using the PRISMA method 


\section{Results}

Based on the literature search process using the PRISMA method, 191 documents were found published in 2020-2021 with full text and using English. After the title and abstract screening process, there was 1 double document, 112 irrelevant documents because they did not discuss factors related to the acceptance of the COVID-19 vaccine, and 78 relevant ones. The results of the full-text study found 50 papers that did not discuss factors related to psychosocial aspects and the results of the study did not show a relationship between psychosocial aspects and the acceptance of the COVID-19 vaccine. So the number of documents to be analyzed is 28 studies. The results of the systematic review are shown in table 1.

Table 1. Characteristics of Studies

\begin{tabular}{|c|c|c|c|c|}
\hline Author, Year, Title & Location & $\begin{array}{l}\text { Psychosocial aspects variables that } \\
\text { affect the acceptance of Covid-19 } \\
\text { Vaccines }\end{array}$ & OR/AOR (CI 95\%) & p-Value \\
\hline $\begin{array}{l}\text { Tsai, Feng-Jen Yang, Hsiu-Wen Lin, Chia- } \\
\text { Ping Liu, Jeffrey Zen. 2021. Acceptability of } \\
\text { COVID-19 Vaccines and Protective Behavior } \\
\text { among Adults in Taiwan: Associations } \\
\text { between Risk Perception and Willingness to } \\
\text { Vaccinate against COVID-19.10 }\end{array}$ & Taiwan & $\begin{array}{l}\text { - Education (low) } \\
\text { - Job status (not working) }\end{array}$ & $\begin{array}{l}2.100(1.550-2.844) \\
1.442(1.056-1.970)\end{array}$ & $\begin{array}{c}<0.001 \\
0.021\end{array}$ \\
\hline $\begin{array}{l}\text { El-Elimat T, AbuAlSamen MM, Almomani } \\
\text { BA, Al-Sawalha NA, Alali FQ. } 2021 . \\
\text { Acceptance and attitudes toward COVID- } 19 \\
\text { vaccines: a cross-sectional study from } \\
\text { Jordan. }{ }^{2}\end{array}$ & Jordan & $\begin{array}{l}\text { - Employment status (work) } \\
\text { - Don't believe there's a conspiracy } \\
\text { behind COVID-19 } \\
\text { - Trust in COVID-19 information } \\
\text { resources }\end{array}$ & $\begin{array}{l}0.542(0.405-0.725) \\
0.502(0.356-0.709) \\
0.271(0.183-0.400)\end{array}$ & $\begin{array}{l}<0.001 \\
<0.001 \\
<0.001\end{array}$ \\
\hline $\begin{array}{l}\text { Machida M, Nakamura I, Kojima T, Saito R, } \\
\text { Nakaya T, Hanibuchi T, et al.. } 2021 . \\
\text { Acceptance of a COVID-19 Vaccine in Japan } \\
\text { during the COVID-19 Pandemic. }{ }^{20}\end{array}$ & Japan & - High income & $0.67(0.47-0.95)$ & 0.026 \\
\hline $\begin{array}{l}\text { Parente DJ, Ojo A, Gurley T, LeMaster JW, } \\
\text { Meyer M, Wild DM, et al. .2021. Acceptance } \\
\text { of COVID-19 vaccination among health } \\
\text { system personnel. }{ }^{11}\end{array}$ & $\begin{array}{l}\text { United } \\
\text { States }\end{array}$ & $\begin{array}{l}\text { - Higher education (post-graduate) } \\
\text { - Race (other than black or African } \\
\text { American) }\end{array}$ & $\begin{array}{l}1.41(1.21-1.65) \\
0.13(0.08-0.21)\end{array}$ & $\begin{array}{l}<0,001 \\
<0.001\end{array}$ \\
\hline $\begin{array}{l}\text { Graeber D, Schmidt-Petri C, Schröder C. } \\
\text { 2021. Attitudes on voluntary and mandatory } \\
\text { vaccination against COVID-19: Evidence } \\
\text { from Germany. }{ }^{21}\end{array}$ & Germany & $\begin{array}{l}\text { - Higher education (college) } \\
\text { - High income } \\
\text { - }\end{array}$ & $\begin{array}{l}0,036(0,061-0,201) \\
0,013(0,001-0,050)\end{array}$ & $\begin{array}{l}0,000 \\
0,045\end{array}$ \\
\hline $\begin{array}{l}\text { Bai W, Cai H, Liu S, Liu H, Qi H, Chen X, et } \\
\text { al.. 2021. Attitudes toward COVID-19 } \\
\text { vaccines in Chinese college students }{ }^{22}\end{array}$ & China & $\begin{array}{l}\text { - Education (health major) } \\
\text { - Supporting family and friends for } \\
\text { COVID-19 vaccination }\end{array}$ & $\begin{array}{l}1.581(1.291-1.935) \\
17.745(12.27-25.66)\end{array}$ & $\begin{array}{l}<0.001 \\
<0.001\end{array}$ \\
\hline $\begin{array}{l}\text { Di Gennaro F, Murri R, Segala FV, Cerruti L, } \\
\text { Abdulle A, Saracino A, et al. 2021. Attitudes } \\
\text { towards Anti-SARS-CoV2 vaccination among } \\
\text { healthcare workers: Results from a national } \\
\text { survey in Italy. }{ }^{23}\end{array}$ & Italy & $\begin{array}{l}\text { - Resources (other than Facebook) } \\
\text { - Types of work (other than health } \\
\text { workers) }\end{array}$ & $\begin{array}{l}1.48(1.06-2.07) \\
1.82(1.31-2.50)\end{array}$ & $\begin{array}{l}<0.0001 \\
<0.0001\end{array}$ \\
\hline $\begin{array}{l}\text { Wirawan GBS, Mahardani PNTY, Cahyani } \\
\text { MRK, Laksmi NLPSP, Januraga PP. } 2021 . \\
\text { Conspiracy Beliefs and Trust as Determinants } \\
\text { of COVID-19 Vaccine Acceptance in Bali, } \\
\text { Indonesia: Cross-sectional Study. }{ }^{24}\end{array}$ & $\begin{array}{l}\text { Bali, } \\
\text { Indonesia }\end{array}$ & $\begin{array}{l}\text { - Don't believe there's a conspiracy } \\
\text { behind COVID-19 } \\
\text { - Trust in conventional media }\end{array}$ & $\begin{array}{l}0.33(0.20-0.54) \\
1.91(1.37-2.65)\end{array}$ & $\begin{array}{l}<0.001 \\
<0.001\end{array}$ \\
\hline $\begin{array}{l}\text { Teixeira da Silva D, Biello K, Lin WY, } \\
\text { Valente PK, Mayer KH, Hightow-Weidman L, } \\
\text { et al. . 2021. COVID-19 Vaccine Acceptance } \\
\text { among an Online Sample of Sexual and } \\
\text { Gender Minority Men and Transgender } \\
\text { Women.25 }\end{array}$ & $\begin{array}{l}\text { United } \\
\text { States }\end{array}$ & $\begin{array}{l}\text { - Social care } \\
\text { - Race (Asian higher than black) } \\
\text { - Trust in medicine }\end{array}$ & $\begin{array}{c}0.081(-0.100-4.641) \\
0.302(0.051-2.378) \\
0.135(-0.060-2.474)\end{array}$ & $\begin{array}{l}0.018 \\
0.001 \\
0.014\end{array}$ \\
\hline $\begin{array}{l}\text { Ditekemena JD, Nkamba DM, Mavoko AM, } \\
\text { Hypolite M, Siewe Fodjo JN, Luhata C, et al.. }\end{array}$ & $\begin{array}{l}\text { Democratic } \\
\text { Republic }\end{array}$ & $\begin{array}{l}\text { - Income level up } \\
\text { - COVID-19 vaccine recipient group }\end{array}$ & $\begin{array}{c}2.91(2.15-3.93) \\
14.45(2.91-71.65)\end{array}$ & $\begin{array}{l}<0,001 \\
<0,001\end{array}$ \\
\hline
\end{tabular}


2021. COVID-19 vaccine acceptance in the Democratic Republic of Congo: a crosssectional survey. ${ }^{13}$

Yang Y, Dobalian A, Ward KD. 2021. COVID-19 Vaccine Hesitancy and Its Determinants Among Adults with a History of Tobacco or Marijuana Use. ${ }^{26}$

Al-Mohaithef M, Padhi BK. 2021. Determinants of COVID-19 vaccine acceptance in Saudi Arabia: a web-based national survey. ${ }^{27}$

Malik AA, McFadden SM, Elharake J, Omer SB. 2020. Determinants of COVID-19 vaccine acceptance in the US 28

Reno C, Maietti E, Fantini MP, Savoia E, Manzoli L, Montalti M, et al. .2021. Enhancing COVID-19 Vaccines Acceptance: Results from a Survey on Vaccine Hesitancy in Northern Italy. ${ }^{29}$

Piltch-Loeb R, Savoia E, Goldberg B, Hughes B, Verhey T, Kayyem J, et al. 2021. Examining the effect of information channel on COVID-19 vaccine acceptance. ${ }^{30}$

Thompson HS, Manning M, Mitchell J, Kim S, Harper FW, Cresswell S, et al. 2021. Factors Associated With Racial/Ethnic GroupBased Medical Mistrust and Perspectives on COVID-19 Vaccine Trial Participation and Vaccine Uptake in the US. ${ }^{31}$

Riad A, Abdulqader H, Morgado M, Domnori S, Košč́k M, Mendes JJ, et al. 2021. Global Prevalence and Drivers of Dental Students' COVID-19 Vaccine Hesitancy. ${ }^{32}$

Viswanath K, Bekalu M, Dhawan D, United Pinnamaneni R, Lang J, McLoud R. 2021. States Individual and social determinants of COVID19 vaccine uptake. ${ }^{14}$

Detoc M, Bruel S, Frappe P, Tardy B, Botelho-Nevers E, Gagneux-Brunon A. 2020. Intention to participate in a COVID-19 vaccine clinical trial and to get vaccinated against COVID-19 in France during the pandemic. ${ }^{33}$

Elhadi M, Alsoufi A, Alhadi A, Hmeida A, Alshareea E, Dokali M, et al. 2021. Knowledge, attitude, and acceptance of healthcare workers and the public regarding the COVID-19 vaccine: a cross-sectional study. ${ }^{34}$

Luk TT, Shengzhi Z, Yongda W, WANG MP, LAM TH. 2021. Prevalence and determinants of SARS-CoV-2 vaccine hesitancy in Hong Kong: a population-based survey. ${ }^{35}$

Guaraldi F, Montalti M, Di Valerio Z, Italy Mannucci E, Nreu B, Monami M, et al.. 2021. Rate and Predictors of Hesitancy toward SARS-CoV-2 Vaccine among Type 2 Diabetic Patients: Results from an Italian Survey. ${ }^{36}$

Abebe H, Shitu S, Mose A. 2021. Understanding of COVID-19 Vaccine Knowledge, Attitude, Acceptance, and Determinates of COVID-19 Vaccine

Libya

Hong

Kong
United

States

Global

- Higher-income levels

- Sources of information (other than conservative sources)

- Identity of political parties (independents and democrats)

- Believing in scientists

- Race/ethnicity (other than black and Hispanic)

- Employment status as a health worker

$1.540(1.275-1.860)$

0,007

$1.79(1.28-2.50)$

$1.25[1.02,1.53]$

$1.75[1.40,2.19]$

$1.81[1.45,2.24]$

$<0.05$

$<0.05$

$<0.05$

B(SE): $0.51(0.08)$

$<0,001$

B(SE): $-0.21(0.09)$

B(SE): $-0.25(0.12)$

0,02

0,04

$<0,01$

$0,55(0,36-0,83)$

$1,46(0,91-2,33)$

$3.56(2.44-5.2)$

$0,46(0,31-0,68)$

France

$$
\begin{array}{cc}
6.04(4.41-8.23) & <0,001 \\
0,46(0,36-0,58) & <0,001 \\
& \\
2.62(1.23-5.55) & <0,001
\end{array}
$$

- Have a family member or friend
infected with COVID-19

$1.09(1.02-1.18)$

0,01

$0.89(0.84-0.97)$

0,004

- Not a smoker

- Alcohol consumption

- Strong knowledge of COVID-19 transmission

- Higher Education Level (college)

Ethiopia

\footnotetext{
- Higher Education Level (High School and Above)

- Have good knowledge related to COVID-19 vaccine
}

$0,15(0.05-0.47)$

0,001

$1.82(1.34-2.47)$

$0.62(0.46-0.85)$

$<0.001$

0.003

$2.63(1.55-4.45) \quad<0.001$

$2.59(1.52-4.39) \quad<0.001$ $2.59(1.67-4.02) \quad<0.001$ 
Acceptance Among Adult Population in Ethiopia. $^{17}$

Mir HH, Parveen S, Mullick NH, Nabi S. 2021. Using structural equation modeling to

India predict Indian people's attitudes and intentions towards COVID-19 vaccination. ${ }^{19}$

Sun Y, Chen X, Cao M, Xiang T, Zhang J, Wang P, et al. 2021. Will Healthcare Workers Accept a COVID-19 Vaccine When It Becomes Available A Cross-Sectional Study in China. ${ }^{37}$

Ehde DM, Roberts MK, Herring TE, Alschuler KN. 2021. Willingness to obtain COVID-19 vaccination in adults with multiple sclerosis in the United States. ${ }^{38}$

Gan L, Chen Y, Hu P, Wu D, Zhu Y, Tan J, et al. 2021. Willingness to Receive SARS-CoV2 Vaccination and Associated Factors among Chinese Adults: A Cross-Sectional Survey..$^{18}$

Zewude B, Habtegiorgis T. 2021. Willingness to Take COVID-19 Vaccine Among People Most at Risk of Exposure in Southern Ethiopia. ${ }^{39}$

China

China
- Social norms
- Trust in the COVID-19 vaccine

- Staying with the elderly

$1.928(1.074-3,462)$

0.028

United

- High level of education

- Trust in Covid-19-related resources

$\beta=0.20$

$<0.001$

- High level of education (college

- Believe in the effectiveness of the COVID-19 vaccine

Ethiopia - The precept that the government reports on the prevalence and mortality rate of COVID-19 is the real thing

- Have close relatives infected with COVID-19

Table 2. The most frequently found variables

\begin{tabular}{lc}
\hline \multicolumn{1}{c}{ Variables } & The total of articles \\
\hline The high education level & 9 \\
The high-income level & 6 \\
Race (other than black race) & 6 \\
Type of work (other than health workers) & 2 \\
The confidence in the information source of Covid-19 & 2 \\
The trust in the existence of Covid-19 & 2 \\
Trust in science and scientists/medical personnel & 2 \\
Have a family member or friend who is infected with Covid-19 & 2 \\
\hline
\end{tabular}

Based on table 2, the variable most often associated with receiving the covid-19 vaccine is the high education level, the high-income level, race (other than black race), and type of work (other than health workers). Then followed by the confidence in the information source of COVID-19, the trust in the existence of COVID-19, trust in science and scientists/medical personnel, and have a family member or friend who is infected with COVID-19. Besides that, several variables will be discussed in the discussion section.

\section{Discussion}

The level of education has a significant influence on people's desire to be vaccinated against COVID-19. Nine articles show that respondents with higher education (above high school) are more receptive to being vaccinated. According to Abebe H, Shitu S, and Mose A, this is possible because those with higher education find it easier to understand the importance or benefits of the COVID-19 vaccination. ${ }^{17}$ In addition, they have more awareness of the prevention of health problems associated with the COVID-19 pandemic. $^{17}$ Al-Mohaithef Research, M., \& Padhi, B. K. also stated that 
improving the status of education can be one of the strategies to achieve complete vaccination in reducing any disease. ${ }^{27}$ While the results of research in Taiwan show respondents with low education are easier to receive the COVID-19 vaccine. ${ }^{10}$ Tsai, et.al explained this might be due to distrust of the government in those who are more highly educated. ${ }^{10}$

Educational background is also related to the respondents' desire to receive the COVID-19 vaccine. Bai Wei et.al's research on university students in China showed that students with healthrelated majors were more receptive to being vaccinated than students majoring in health. ${ }^{22}$ This happens because students majoring in health consider them to have a higher chance of infection, so vaccination is urgently needed for their protection. ${ }^{22}$

High income relates to respondents' desire to receive vaccines. ${ }^{13,20,21}$ According to Ditekemena, et.al respondents with high-income levels may have better access and quality. Employment status is related to acceptance or desire to be vaccinated either at work or unfaithful. Tsai et.al research showed that unworked respondents were more likely to receive the vaccine. While El-Elimat $\mathrm{T}$ et.al research showed, that respondents with the status of work are easier to receive vaccination. ${ }^{12}$ For this type of work, Detoc Maelle et.al showed that respondents who worked as health workers were easier to receive vaccines than other types of work. ${ }^{33}$ Meanwhile, Di Gennaro, Francesco et.al showed that respondents with non-health workers' jobs are easier to receive vaccines. ${ }^{23}$ In Gennaro, Francesco et.al made it clear that this might be due to a lack of attention to the uncertainty of the quality of vaccines that make health workers doubt. ${ }^{23}$

The race is one of the factors that influence the acceptance of the COVID-19 vaccine in various countries. Six articles analyze that the black race is more difficult or even refuses to administer the COVID-19 vaccine. ${ }^{11,14,25,26,28,31}$ This may reflect a distrust of medical personnel in general but may be exacerbated by a lack of minority representation in clinical trials related to COVID-19. ${ }^{11,25,26,40}$

The desire to be vaccinated is also influenced by the confidence in the information source of COVID-19. ${ }^{12,38}$ Such sources of information can shape people's acceptance or rejection of vaccines, so it is important to disseminate transparent and accurate information about the safety and efficacy of vaccines to gain the trust of a skeptical and skeptical public. ${ }^{12}$ Therefore, gaining an understanding of the most trusted resources for obtaining information about the COVID-19 vaccine is critical to the success of vaccination campaigns. The sources of information that affect respondents who want to receive vaccines are conventional media such as national TV, national and local newspapers, radio; not from social media such as Facebook; and not conservative sources. ${ }^{14,23,24,30}$

The trust in the existence of COVID-19 affects respondents to receive vaccines. ${ }^{13,39}$ Those who believe that COVID-19 exists receive well for vaccinating. This is also influenced by distrust of the conspiracy behind the existence of COVID-19 because respondents who believe in the COVID-19 conspiracy doubt the origin, nature, severity, and risk posed by COVID-19, so the vaccination program is hampered. ${ }^{24,41-43}$ Based on this explanation, the respondent's knowledge is related to the process of receiving vaccinations. Abebe, $\mathrm{H}$, et.al and Lux et.al research, showed that respondents 
who have sufficient knowledge related to the COVID-19 vaccine and the way COVID-19 is transmitted are easier to receive vaccinations. ${ }^{17,35}$ This explanation is similar to the research results by Teixeira da Silva, et.al regarding trust in medicine, research by Viswanath, et.al regarding trust in science and scientists, and research by Gan Lin, et.al and Mir, et.al regarding trust in vaccines. and its effectiveness COVID-19. ${ }^{14,18,19,25}$ In addition to trust, the precept that government reports on the prevalence and mortality rate of COVID-19 is the real thing, encouraging respondents to be ready to receive vaccines. ${ }^{39}$

Research by Elhadi M, et.al and Zewude, B et.al showed that having family or friends infected with COVID-19 was related to respondents' desire to be vaccinated. ${ }^{34,39}$ The two studies do not explain the reasons for the variable relationship, but this could likely be because the presence of infected family or friends makes respondents aware of the dangers of COVID-19 transmission, as previously described. ${ }^{35}$ Then, respondents who support their family and friends for the COVID-19 vaccination relate to the respondent's desire to be vaccinated. This shows that when a person has helped others to be vaccinated, then of course he will do the same for themself. This is in line with Mir, Hilal Hamid, et.al research which explains that social norms consisting of family, friends, and doctors who have good relationships with respondents relate to the respondent's readiness to receive vaccines. ${ }^{19}$ Family-related factors related to vaccine acceptance are staying with the elderly. ${ }^{37}$ This is because older people are more susceptible to infectious diseases that may make respondents more prepared to receive vaccines so as not to transmit the virus to their family members. ${ }^{37}$ This may be one of the reasons that those who are married are easier for vaccine recipients, such as research conducted by Al-Mohaithef \& Padhi, BK. ${ }^{27}$

Teixeira da Silva et.al showed that social care, where respondents do not care about social issues such as fear of discrimination after obtaining a vaccine is a contributing factor for receiving vaccines. ${ }^{25}$ Viswanath, $\mathrm{K}$, et.al explained that political ideology measured through party identification is strongly related to the reluctance to obtain the COVID-19 vaccine and other studies have shown the same that ideology is associated with believing in anti-vaccine conspiracies. ${ }^{14}$

Research Lux, TT, et.al pointed out that respondents who smoked were more hesitant to receive the vaccine. This can happen because there is information on social media that explains that smoking can protect against COVID-19. So that contributes to the low desire of smokers to be vaccinated. In addition, Lux, TT, et.al explained that respondents with a habit of drinking alcohol had lower doubts to be vaccinated. ${ }^{35}$ This may be because, during the second wave of the COVID-19 outbreak in Hong Kong, the largest local outbreak group involved customers and bar workers. ${ }^{44}$ Thus, the presence of high risk to bar visitors makes it easier for them to receive vaccines.

\section{Conclusion}

This systematic review found that the psychosocial aspects that had the most influence on the acceptance of the COVID-19 vaccine were education level, income level, and race. This is followed by the type of work, trust in the existence of COVID-19, trust in COVID-19 information sources, trust 
in medical and health workers, and having family members or friends who are infected with COVID19. However, this literature review does not show all the factors that influence the acceptance of the COVID-19 vaccine, only related to psychosocial aspects. In addition, many other factors may not be listed in this systematic review, which is limited to only one database and articles that can be accessed for free. Nevertheless, the COVID-19 vaccine delivery program can consider and address the challenges of acceptance and rejection of vaccines from the public based on these psychosocial aspects.

\section{Funding}

No funding for the study

\section{Conflict of Interest}

The authors declare that this study has no conflict of interest.

\section{Reference}

1. WHO. Archived: WHO Timeline - COVID-19 2020 [cited 202122 April]. Available from: https://www.who.int/news/item/27-04-2020-who-timeline---covid-19.

2. WHO. WHO Coronavirus (COVID-19) Dashboard 2021 [cited 2021. Available from: https://covid19.who.int/?gclid=CjwKCAjwmv-

DBhAMEiwA7xYrdz4_GRbM0Kw3szYcIJFj2YRqPVNfHTLsM5LFmEsacpRAy_yLImX7xoC0w4QAvD_BwE.

3. Gugus Tugas Percepatan Penaganan COVID-19. Peta Sebaran 2021 [Available from: https://covid19.go.id/peta-sebaran.

4. World Health Organization. Coronavirus disease (COVID-19): Vaccines. 2020.

5. World Health Organization. Getting the COVID-19 Vaccine 2021 [Available from: https://www.who.int/news-room/feature-stories/detail/getting-the-covid-19-vaccine.

6. World Health Organization. COVAX: Working for global equitable access to COVID-19 vaccines 2021 [Available from: https://www.who.int/initiatives/act-accelerator/covax.

7. Daly M, Robinson E. Willingness to vaccinate against COVID-19 in the US: representative longitudinal evidence from April to October 2020. American journal of preventive medicine. 2021;60(6):766-73.

8. Lazarus JV, Ratzan SC, Palayew A, Gostin LO, Larson HJ, Rabin K, Kimball S, El-Mohandes A. A global survey of potential acceptance of a COVID-19 vaccine. Nature medicine. 2020:1-4.

9. Ichsan DS, Hafid F, Ramadhan K, Taqwin T. Determinan Kesediaan Masyarakat menerima Vaksinasi Covid-19 di Sulawesi Tengah. Poltekita: Jurnal Ilmu Kesehatan. 2021;15(1):1-11. 
10. Tsai F-J, Yang H-W, Lin C-P, Liu JZ. Acceptability of COVID-19 Vaccines and Protective Behavior among Adults in Taiwan: Associations between Risk Perception and Willingness to Vaccinate against COVID-19. International Journal of Environmental Research and Public Health. 2021;18(11):5579.

11. Parente DJ, Ojo A, Gurley T, LeMaster JW, Meyer M, Wild DM, Mustafa RA. Acceptance of COVID-19 vaccination among health system personnel. The Journal of the American Board of Family Medicine. 2021;34(3):498-508.

12. El-Elimat T, AbuAlSamen MM, Almomani BA, Al-Sawalha NA, Alali FQ. Acceptance and attitudes toward COVID-19 vaccines: a cross-sectional study from Jordan. Plos one. 2021;16(4):e0250555.

13. Ditekemena JD, Nkamba DM, Mavoko AM, Hypolite M, Siewe Fodjo JN, Luhata C, Obimpeh M, Van Hees S, Nachega JB, Colebunders R. COVID-19 vaccine acceptance in the Democratic Republic of Congo: a cross-sectional survey. Vaccines. 2021;9(2):153.

14. Viswanath K, Bekalu M, Dhawan D, Pinnamaneni R, Lang J, McLoud R. Individual and social determinants of COVID-19 vaccine uptake. BMC Public Health. 2021;21(1):1-10.

15. Alqudeimat $Y$, Alenezi D, AlHajri B, Alfouzan H, Almokhaizeem Z, Altamimi S, Almansouri W, Alzalzalah S, Ziyab AH. Acceptance of a COVID-19 Vaccine and Its Related Determinants among the General Adult Population in Kuwait. Medical Principles and Practice. 2021.

16. Padhi BK, Al-Mohaithef M. Determinants of COVID-19 vaccine acceptance in Saudi Arabia: a web-based national survey. medRxiv. 2020:2020.05.27.20114413.

17. Abebe H, Shitu S, Mose A. Understanding of COVID-19 Vaccine Knowledge, Attitude, Acceptance, and Determinates of COVID-19 Vaccine Acceptance Among Adult Population in Ethiopia. Infection and Drug Resistance. 2021;14:2015.

18. Gan L, Chen Y, Hu P, Wu D, Zhu Y, Tan J, Li Y, Zhang D. Willingness to Receive SARS-CoV2 Vaccination and Associated Factors among Chinese Adults: A Cross Sectional Survey. International Journal of Environmental Research and Public Health. 2021;18(4):1993.

19. Mir HH, Parveen S, Mullick NH, Nabi S. Using structural equation modeling to predict Indian people's attitudes and intentions towards COVID-19 vaccination. Diabetes \& Metabolic Syndrome: Clinical Research \& Reviews. 2021;15(3):1017-22.

20. Machida M, Nakamura I, Kojima T, Saito R, Nakaya T, Hanibuchi T, Takamiya T, Odagiri Y, Fukushima N, Kikuchi H, Amagasa S. Acceptance of a COVID-19 Vaccine in Japan during the COVID-19 Pandemic. Vaccines. 2021;9(3):210.

21. Graeber D, Schmidt-Petri C, Schröder C. Attitudes on voluntary and mandatory vaccination against COVID-19: Evidence from Germany. PloS one. 2021;16(5):e0248372.

22. Bai W, Cai H, Liu S, Liu H, Qi H, Chen X, Liu R, Cheung T, Su Z, Ng CH, Xiang YT. Attitudes toward COVID-19 vaccines in Chinese college students. International journal of biological sciences. 2021;17(6):1469. 
23. Di Gennaro F, Murri R, Segala FV, Cerruti L, Abdulle A, Saracino A, Bavaro DF, Fantoni M. Attitudes towards Anti-SARS-CoV2 vaccination among healthcare workers: Results from a national survey in Italy. Viruses. 2021;13(3):371.

24. Wirawan GBS, Mahardani PNTY, Cahyani MRK, Laksmi NLPSP, Januraga PP. Conspiracy Beliefs and Trust as Determinants of COVID-19 Vaccine Acceptance in Bali, Indonesia: Crosssectional Study. Personality and Individual Differences. 2021:110995.

25. Teixeira da Silva D, Biello K, Lin WY, Valente PK, Mayer KH, Hightow-Weidman L, Bauermeister JA. COVID-19 Vaccine Acceptance among an Online Sample of Sexual and Gender Minority Men and Transgender Women. Vaccines. 2021;9(3):204.

26. Yang Y, Dobalian A, Ward KD. COVID-19 Vaccine Hesitancy and Its Determinants Among Adults with a History of Tobacco or Marijuana Use. Journal of Community Health. 2021:1-9.

27. Al-Mohaithef M, Padhi BK. Determinants of COVID-19 vaccine acceptance in Saudi Arabia: a web-based national survey. Journal of multidisciplinary healthcare. 2020;13:1657.

28. Malik AA, McFadden SM, Elharake J, Omer SB. Determinants of COVID-19 vaccine acceptance in the US. EClinicalMedicine. 2020;26:100495.

29. Reno C, Maietti E, Fantini MP, Savoia E, Manzoli L, Montalti M, et al. Enhancing COVID-19 Vaccines Acceptance: Results from a Survey on Vaccine Hesitancy in Northern Italy. Vaccines. 2021;9(4):378.

30. Piltch-Loeb R, Savoia E, Goldberg B, Hughes B, Verhey T, Kayyem J, Miller-Idriss C, Testa M. Examining the effect of information channel on COVID-19 vaccine acceptance. Plos one. 2021;16(5):e0251095.

31. Thompson HS, Manning M, Mitchell J, Kim S, Harper FW, Cresswell S, Johns K, Pal S, Dowe B, Tariq M, Sayed N. Factors Associated With Racial/Ethnic Group-Based Medical Mistrust and Perspectives on COVID-19 Vaccine Trial Participation and Vaccine Uptake in the US. JAMA Network Open. 2021;4(5):e2111629-e.

32. Riad A, Abdulqader H, Morgado M, Domnori S, Koščík M, Mendes JJ, Klugar M, Kateeb E. Global Prevalence and Drivers of Dental Students' COVID-19 Vaccine Hesitancy. Vaccines. 2021;9(6):566.

33. Detoc M, Bruel S, Frappe P, Tardy B, Botelho-Nevers E, Gagneux-Brunon A. Intention to participate in a COVID-19 vaccine clinical trial and to get vaccinated against COVID-19 in France during the pandemic. Vaccine. 2020;38(45):7002-6.

34. Elhadi M, Alsoufi A, Alhadi A, Hmeida A, Alshareea E, Dokali M, Abodabos S, Alsadiq O, Abdelkabir M, Ashini A, Shaban A. Knowledge, attitude, and acceptance of healthcare workers and the public regarding the COVID-19 vaccine: a cross-sectional study. BMC public health. 2021;21(1):1-21.

35. Luk TT, Shengzhi Z, Yongda W, WANG MP, LAM TH. Prevalence and determinants of SARSCoV-2 vaccine hesitancy in Hong Kong: a population-based survey. Vaccine. 2021. 
36. Guaraldi F, Montalti M, Di Valerio Z, Mannucci E, Nreu B, Monami M, Gori D. Rate and Predictors of Hesitancy toward SARS-CoV-2 Vaccine among Type 2 Diabetic Patients: Results from an Italian Survey. Vaccines. 2021;9(5):460.

37. Sun Y, Chen X, Cao M, Xiang T, Zhang J, Wang P, Dai H. Will Healthcare Workers Accept a COVID-19 Vaccine When It Becomes Available? A Cross-Sectional Study in China. Frontiers in Public Health. 2021;9:609.

38. Ehde DM, Roberts MK, Herring TE, Alschuler KN. Willingness to obtain COVID-19 vaccination in adults with multiple sclerosis in the United States. Multiple Sclerosis and Related Disorders. 2021;49:102788.

39. Zewude B, Habtegiorgis T. Willingness to Take COVID-19 Vaccine Among People Most at Risk of Exposure in Southern Ethiopia. Pragmatic and Observational Research. 2021;12:37.

40. O'Callaghan KP, Blatz AM, Offit PA. Developing a SARS-CoV-2 vaccine at warp speed. Jama. 2020.

41. Miller JM. Do COVID-19 conspiracy theory beliefs form a monological belief system? Canadian Journal of Political Science/Revue canadienne de science politique. 2020;53(2):319-26.

42. Oleksy T, Wnuk A, Maison D, Łyś A. Content matters. Different predictors and social consequences of general and government-related conspiracy theories on COVID-19. Personality and individual differences. 2021;168:110289.

43. Karlsson LC, Soveri A, Lewandowsky S, Karlsson L, Karlsson H, Nolvi S, Karukivi M, Lindfelt M, Antfolk J. Fearing the disease or the vaccine: The case of COVID-19. Personality and individual differences. 2021 Apr 1;172:110590.

44. Dillon A. Clustering and superspreading potential of severe acute respiratory syndrome coronavirus 2 (SARS-CoV-2) infections in Hong Kong. Research Square. 2020. 